\title{
Impact of open burning of crop residues on air pollution and climate change in Indonesia
}

\author{
Ade Andini ${ }^{1,2}$, Sébastien Bonnet ${ }^{1,2, *}$, Patrick Rousset ${ }^{1,2,3}$ and Udin Hasanudin ${ }^{4}$ \\ ${ }^{1}$ The Joint Graduate School of Energy and Environment, King Mongkut's University of Technology Thonburi, Bangkok, Thailand \\ ${ }^{2}$ Center for Energy Technology and Environment, Ministry of Education, Bangkok, Thailand \\ ${ }^{3}$ CIRAD - Agricultural Research for Development Biomass, Wood, Energy, Bioproducts team Internal Research Unit - BioWooEB, \\ Montpellier, France \\ ${ }^{4}$ Research and Development Center for Tropical Biomass, Institute for Research and Community Services, University of Lampung, \\ Lampung, Indonesia
}

\begin{abstract}
Crop residues are subjected to open burning in Indonesia. These farming practices were studied to determine the proportion of open burned and their contribution to air pollution based on crop and air pollutant specific emission factors. On an annual basis, it was estimated that 45 million tonnes of crop residues are open burned. This leads to emission of greenhouse gases and toxic pollutants. On an average, $\mathrm{CO}_{2}$ and $\mathrm{CO}$ dominate the overall emissions with $90 \%$ and $8 \%$ respectively. The remaining $2 \%$ are contributed by $\mathrm{CH}_{4}, \mathrm{SO}_{2}, \mathrm{NO}_{x}, \mathrm{NH}_{3}, \mathrm{~N}_{2} \mathrm{O}, \mathrm{NMVOC}$ and particulate matter. Climate charging emissions were assessed to contribute $12-14 \%$ towards global warming potential by the global crop residues open burning.
\end{abstract}

Keywords: Crop residues, emission factors, global warming, Indonesia, open burning.

BIOMASs burning is defined as the combustion of world's living and dead vegetation, including grasslands, forests and agricultural lands following the harvest for land clearing and landuse change. It is not limited to one area but is a global phenomenon and has been recognized as a key driver for global change ${ }^{1}$. Biomass burning is one of the major sources of gaseous and particulate emissions to the atmosphere ${ }^{2}$ and studies on climate change have shown that it is more frequent during dry season ${ }^{3}$. It contributes to global environmental change by affecting local, regional and global air quality as well as by disrupting rainfall patterns. Most of the world's biomass burning occurs in the tropics and includes among others, tropical forests, savannas and agricultural land after the harvest ${ }^{4}$. A study on air quality in Asia indicated that biomass burning constitutes a major source of air pollution, particularly in China, India, Indonesia and countries of the Mekong River Basin Sub-Region ${ }^{5}$.

Air pollutants emitted from biomass open burning whether forest fires or crop residues, include common greenhouse gases (GHGs) such as carbon dioxide $\left(\mathrm{CO}_{2}\right)$,

*For correspondence. (e-mail: sebastien_b@jgsee.kmutt.ac.th) carbon monoxide $(\mathrm{CO})$, methane $\left(\mathrm{CH}_{4}\right)$ and nitrous oxide $\left(\mathrm{N}_{2} \mathrm{O}\right)$ as well as volatile organic compounds (VOCs), ammonia $\left(\mathrm{NH}_{3}\right)$, sulphur dioxide $\left(\mathrm{SO}_{2}\right)$, nitrogen oxides $\left(\mathrm{NO}_{x}\right)$ and particulate matter (PM). Agricultural residues burning also releases a huge amount of pollutants to the atmosphere, which apart from the above includes aerosols and hydrocarbons ${ }^{6-9}$. Haze formation is one of the major impacts of open burning. It is a recurrent issue of concern in Southeast Asia where biomass-burning haze has become an important source of tropospheric ozone and the aerosols resulting from such events have contributed largely to the formation of atmospheric brown clouds ${ }^{10,11}$. Vegetation fires in Sumatra and Kalimantan Islands in Indonesia have caused trans-boundary haze pollution events affecting the entire Southeast Asian region; the most well-known event occurred in 1997-98 (refs 12, 13). In October 2015, vegetation fires in Kalimantan resulted in the pollution standard index (PSI) reaching a level of 2400, the maximum hazardous level being 1000 . The daily GHG emissions from Indonesia's fires in October 2015 were estimated at 15.95 million tonnes $\mathrm{CO}_{2 \mathrm{eq}}$ which comparatively exceeded the emissions from the entire US. If Indonesia could curtail open burning of biomasses, it would be able to meet its stated target of reducing GHG emissions by $29 \%$ by the year 2030 (refs 14, 15).

Indonesia is an agrarian country consisting of more than 17,000 islands. It is composed of five major islands namely Sumatra, Kalimantan, Java, Sulawesi and Papua. $\mathrm{FAO}^{16}$ revealed that $30 \%$ of Indonesia's land is dedicated to agricultural production. The major food crops produced in the country based on harvested area are rice, corn, cassava, soybean and peanut. Oanh et al. ${ }^{17}$ indicated that post harvest, a proportion of crop residues is used by farmers as composting material and animal feed, for roof thatching, and as fuel for domestic use. However, for a number of reasons including limited access to labour and enhanced access to modern energy, large amount of residues remain unused in the field and subjected to open burning. Such a practice has become an issue of growing concern as responsible for various adverse impacts such as air pollution, climate change and health and economic 


\section{RESEARCH ARTICLES}

impacts. These also affect bilateral relationships with neighbouring countries ${ }^{18-20}$. Although area-wise forest fires dominate with about $70 \%$ of its surface subjected to open burning, the largest emissions $(\sim 80 \%)$ are observed from agricultural burning followed by forest fire and Municipal Solid Waste (MSW) ${ }^{20}$. Several studies have attempted to assess potential emissions from crop residues burning using satellite data (fire hotspots), default activity data and emission factors $5,18,20,21-23$. However, the results were characterized by lots of uncertainties. Hence results should be refined using country- and crop-specific information in particular with regard to the proportion of residues subjected to open burning and the emissions factors used.

The objectives of this study were: (1) to determine the proportion of crop residues subjected to open burning in Indonesia based on farming practices, and (2) to estimate the corresponding emissions of air pollutants and potential contribution to climate change in the form of global warming potential (GWP).

\section{Methodology}

\section{Assessment of farming practices}

In order to study farming practices that represent the situation in Indonesia, an island with the highest crop production potential was selected. For the year 2015, based on the data from the Indonesian Ministry of Agriculture (IMA) ${ }^{24}$, Sumatra was identified as the suitable island. Similarly, using the same data ${ }^{24}$, the Lampung province in Sumatra, with a significant crop variety and production potential was considered for the field survey. The field survey was conducted using a questionnaire to study farming practices, including open burning of crop residues. The sampling size $(n)$ for the survey was determined based on the Yamane equation ${ }^{25}$ as

$$
n=\frac{N}{1+N(e)^{2}},
$$

where $N$ is the population of farmers and $e$ is the desired level of precision, also called sampling error, and was set at $95 \%$. It represents the range in which the true value of the population is estimated to lie. Based on eq. (1), a sample of 400 farmers was selected for interview spread over 13 areas in the province.

The questionnaire for the field survey was designed as detailed by Andini et al. ${ }^{26}$. It consisted several sections, including locations of agricultural production sites and types of crops cultivated and detailed information about the farming practices followed by farmers. From the survey, information about the proportion of crop residues burned in the field and proportion used for other purposes was identified. The data collected from the survey was divided into two groups, i.e. crop residues unburned and crop residues burned. Concerning the fraction of crop residues unburned, the data was further subdivided into two groups, namely crop residues used and crop residues unused. Regarding the utilization of crop residues, there were five main areas, such as animal feed, fertilizer, fuel, food and other purposes. In case of open burning of crop residues, there were three main areas, such as soil enrichment (nutrients), pest control and elimination of residues.

\section{Assessment of crop residues open burned and emissions}

Based on data collected from the field survey, the amount of crop residues subjected to open burning was estimated for each of the crops studied, using eq. (2) as

$$
Q=P \times R \times B,
$$

where for a specific crop, $Q$ is the quantity of crop residues subjected to open burning (mg/year) and $P$ is the crop production (mg/year). The data was obtained from IMA $^{24} ; R$ the residue-to-product ratio and refers to the amount of crop residues produced per amount of product (on a dry mass basis). Crop-specific values for this parameter were estimated based on data from Permadi and $\mathrm{Oanh}^{20} ; B$ is the proportion of crop residues subjected to open burning. Values for this parameter, which is country- and crop-specific, and mainly influenced by farming practices, were determined through the questionnaire survey performed with farmers.

As reported in Gadde et al. ${ }^{18}$, the approach to quantify air pollutants emissions from biomass open burning is based on the methodology proposed by the Intergovernmental Panel on Climate Change (IPCC) guidelines 2006 (ref. 27), except for the step to quantify the amount of crop residues subjected to open burning. Air pollutant emissions from specific crop residues field burning were quantified using eq. (3)

$$
E_{\mathrm{a}}=Q \times \eta \times E F_{\mathrm{a}},
$$

where for a particular crop residue, $E_{\mathrm{a}}$ the emission of $a$ (mg/year) and $\eta$ the fraction of biomass oxidized during combustion. Biomass specific values were collected from Turn et al. ${ }^{28}$; EF the emission factor of $a$ of dry crop residues $(\mathrm{g} / \mathrm{kg})$. Crop-specific values were obtained from literature review; $Q$ the quantity of crop residues subjected to open burning (mg/year) (for a specific crop); $a$ the pollutant species.

\section{Results and discussion}

\section{Proportion of crop residues subject to open burning}

Information from $\mathrm{IMA}^{24}$ shows that rice, corn, cassava and sugarcane are the top four main crops produced in 

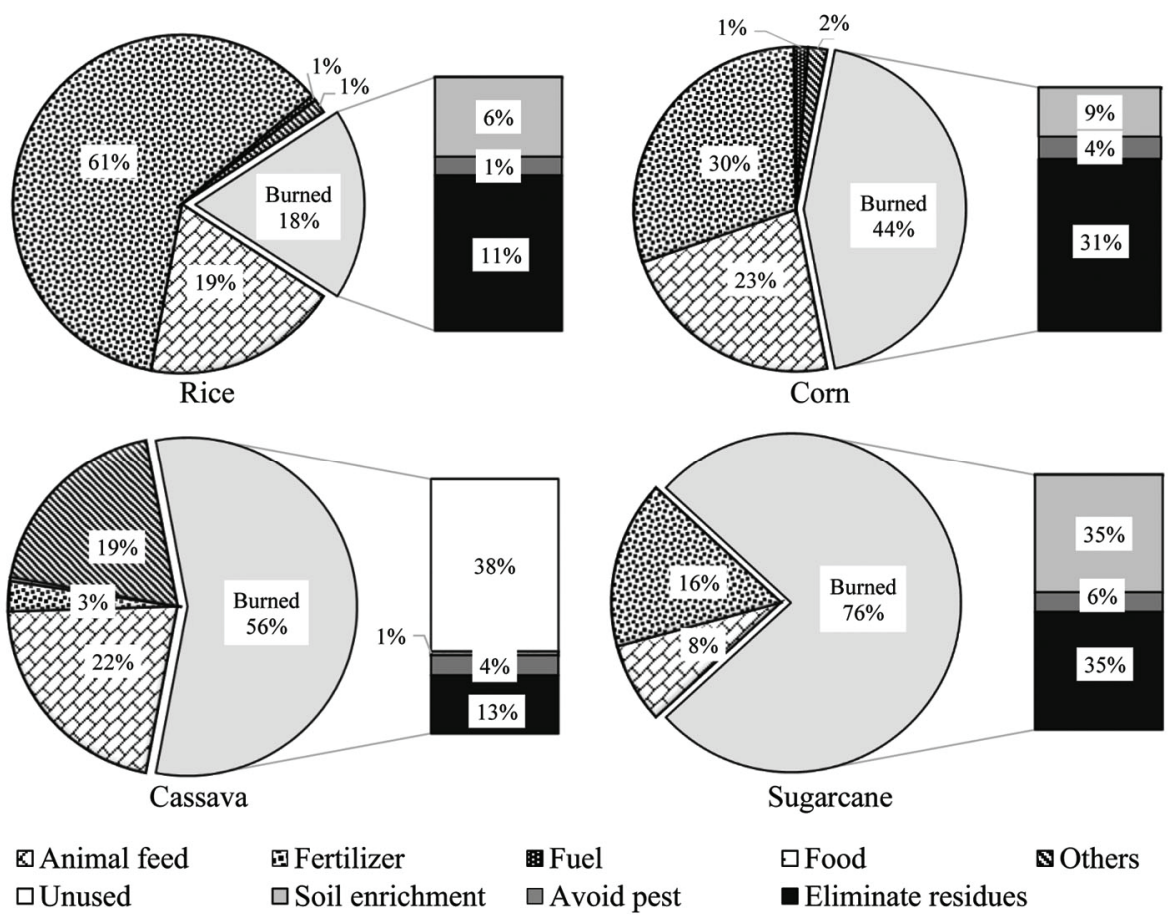

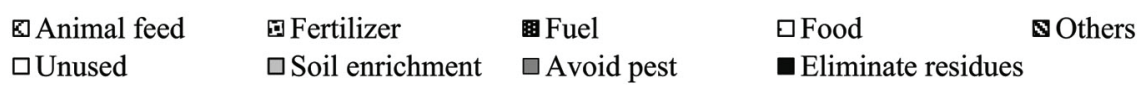

Figure 1. Proportion of crop residues burned and unburned.

Table 1. Crop production, residue generation and coefficients used for inventory

\begin{tabular}{lcccc}
\hline Crop & $\mathrm{P}\left(10^{6} \text { tonnes year }^{-1}\right)^{\mathrm{a}}$ & $\mathrm{R}^{\mathrm{b}}$ & $\mathrm{B}(\%)$ & $\mathrm{Q}\left(10^{6}\right.$ tonnes year $\left.^{-1}\right)$ \\
\hline Rice & 70.85 & 1.49 & 18 & 19.30 \\
Cassava & 23.44 & $1.42^{\mathrm{c}}$ & 56 & 18.50 \\
Corn & 19.01 & 0.80 & 44 & 6.70 \\
Sugarcane & 2.58 & 0.21 & 76 & 0.40 \\
Total & 115.88 & & & 44.90 \\
\hline
\end{tabular}

${ }^{\mathrm{a}}$ Ministry of Agriculture of Indonesia ${ }^{24} ;{ }^{b}$ Permadi and $\mathrm{Oanh}^{20}$; ${ }^{\mathrm{c}} \mathrm{Koopman}$ and Koppejan ${ }^{44}$.

Indonesia whose residues are also subjected to open burning. Rice is the dominant crop with a largest area harvested, i.e. $12.5 \mathrm{~m}$ ha, followed by corn with $3.3 \mathrm{~m}$ ha, cassava with $0.9 \mathrm{~m}$ ha and sugarcane with $0.4 \mathrm{~m}$ ha.

According to data obtained from the survey and the corresponding results reported in Figure 1, it is observed that more than $80 \%$ of rice residues and more than half of all corn residues are unburned and used mainly as fertilizers and animal feed. For sugarcane, the reverse is observed with over three quarters of its residues being open burned. The remaining fraction is used mainly as fertilizer and animal feed as is the case for rice and corn. The results obtained for cassava, which is a perennial woody shrub, are quite different. It is observed that $80 \%$ of its residues are unburned, almost half of which is unused and consists mainly of stalk and stubbles. The other half of the unburned residues consist of leaves, which are mainly used as animal feed and some other unidentified purposes. Concerning the fraction of crop residues open burned, some similarities are also observed for rice, corn and sugarcane in terms of soil enrichment, next crop preparation and elimination of residues. For rice and corn, having two or three cycles of production and harvest in a year, open burning is mainly practised to eliminate residues for next crop preparation. For sugarcane, burning of crop residues is practised prior to harvesting to eliminate residues in the case of green harvesting. It is also practised following harvesting to enrich the soil in nutrients for the next ratoon (there can be 3-5 ratoons) as well as to eliminate residues to facilitate for the next production cycle. With regard to cassava, farmers eliminate residues via open burning and to avoid fungal contamination from residues decomposition.

Table 1 shows the details of open burning of rice, corn, cassava and sugarcane residues. Based on the proportion of crop residues subjected to open burning, sugarcane shows the highest amount with $76 \%$, followed by cassava $(56 \%)$, corn $(44 \%)$ and rice $(18 \%)$. These results are comparatively lower than that of a study by Seiler and Crutzen $^{29}$ which reported that $80 \%$ of crop residues are 
Table 2. Crop specific oxidation factors and pollutant specific emission factors

\begin{tabular}{|c|c|c|c|c|c|}
\hline \multicolumn{2}{|l|}{ Description } & \multirow{2}{*}{$\begin{array}{c}\text { Rice straw } \\
0.89\end{array}$} & \multirow{2}{*}{$\begin{array}{c}\text { Corn } \\
0.92\end{array}$} & \multirow{2}{*}{$\begin{array}{c}\text { Cassava } \\
0.68\end{array}$} & \multirow{2}{*}{$\begin{array}{c}\text { Sugarcane } \\
0.68\end{array}$} \\
\hline Oxidation factor & $\eta^{\mathrm{a}}$ & & & & \\
\hline \multirow[t]{12}{*}{ Emission Factors $\left(\mathrm{g} \mathrm{kg}^{-1}\right)$} & $\mathrm{CO}_{2}$ & $1,216^{\mathrm{c}}$ & $2327.14^{\mathrm{h}}$ & $1130^{\mathrm{k}}$ & $1130^{\mathrm{k}}$ \\
\hline & $\mathrm{CO}$ & $179.9^{c}$ & $80.3^{\mathrm{i}}$ & $86.30^{\mathrm{k}}$ & $34.66^{\mathrm{i}}$ \\
\hline & $\mathrm{CH}_{4}$ & $9.59^{\mathrm{c}}$ & $3.4^{\mathrm{i}}$ & $4.56^{\mathrm{k}}$ & $0.41^{\mathrm{i}}$ \\
\hline & $\mathrm{NO}_{x}$ & $3.10^{\mathrm{d}}$ & $3.7^{\mathrm{i}}$ & $0.70^{\mathrm{k}}$ & $2.63^{\mathrm{i}}$ \\
\hline & $\mathrm{N}_{2} \mathrm{O}$ & $0.07^{\mathrm{b}}$ & $0.07^{\mathrm{b}}$ & $0.07^{\mathrm{b}}$ & $0.07^{\mathrm{b}}$ \\
\hline & $\mathrm{NH}_{3}$ & $4.10^{\mathrm{c}}$ & $1.6^{\mathrm{i}}$ & $1.30^{\mathrm{b}}$ & $0.95^{\mathrm{i}}$ \\
\hline & $\mathrm{SO}_{2}$ & $2.00^{\mathrm{e}}$ & $0.44^{\mathrm{j}}$ & $0.216^{\mathrm{k}}$ & $0.216^{\mathrm{k}}$ \\
\hline & NMVOC & $4.00^{f}$ & $4.40^{\mathrm{i}}$ & $4.35^{\mathrm{k}}$ & $2.18^{\mathrm{i}}$ \\
\hline & $\mathrm{PM}_{10}$ & $9.4^{\mathrm{g}}$ & $4.26^{\mathrm{i}}$ & $8.05^{\mathrm{k}}$ & $3.99^{\mathrm{i}}$ \\
\hline & $\mathrm{PM}_{2.5}$ & $4.2^{\mathrm{c}}$ & $4.13^{\mathrm{i}}$ & $3.88^{1}$ & $3.77^{\mathrm{i}}$ \\
\hline & $\mathrm{EC}$ & $0.51^{\mathrm{g}}$ & $0.95^{\mathrm{h}}$ & $0.47^{1}$ & $0.77^{\mathrm{m}}$ \\
\hline & $\mathrm{OC}$ & $2.99^{\mathrm{g}}$ & $2.25^{\mathrm{h}}$ & $0.91^{1}$ & $0.91^{1}$ \\
\hline
\end{tabular}

${ }^{\mathrm{a}}$ Turn et al. ${ }^{28}$; ${ }^{\mathrm{b}}$ Andreae and Merlet ${ }^{32}$ : Default EFs for several types of biomass burning. ${ }^{\mathrm{c}} \mathrm{Christian}$ et $a l .{ }^{33}$ : Specific EFs for rice straw open burning in Indonesia. ${ }^{\mathrm{d}} \mathrm{Kadam}$ et al. ${ }^{34}$ : Specific EFs for rice straw open burning in California. ${ }^{\mathrm{e}}$ Jenkins and Bhatnagar ${ }^{35}$ : Specific EFs for rice straw open burning. ${ }^{\mathrm{f} U S}$ $\mathrm{EPA}^{36}$ : EFs for rice straw from the AP-42 database developed by the USEPA. ${ }^{\mathrm{g} O a n h}$ et al. ${ }^{17}$ : Specific EFs for rice straw open burning in Thailand. ${ }^{\mathrm{h}} \mathrm{Cao}$ et al. ${ }^{37}$ : Specific EFs for corn residues based on combustion tower experiment in China. ${ }^{\mathrm{i}}$ Dennis et $a l .{ }^{38}$ : Specific EFs for corn and sugarcane open burning in Texas. ${ }_{\mathrm{j}}^{\mathrm{L}}$ i et $a l .{ }^{39}$ : Specific EFs for corn stover open burning in China. ${ }^{\mathrm{k}}$ Zhang et $a l .{ }^{40}$ : Default EFs for crop residues open burning in China. ${ }^{1}$ Reddy and Venkataraman ${ }^{41}$ : Default EFs for crop residues open burning in India. ${ }^{\mathrm{m}}$ Penner et $a l .{ }^{42}$ : Specific EFs for sugarcane at developing areas.

open burned in developing countries. Specifically for Asia, Chang et al. ${ }^{30}$ reported much lower values (17$25 \%$ ) for all types of crop residues subjected to open burning. However, Yevich and Logan ${ }^{31}$ reported that in Indonesia $73 \%$ of all types of crop residues are burnt in the field. Sasongko et al. ${ }^{23}$ who studied more specifically rice straw open burning in Indonesia, reported that $43 \%$ of rice straw are open burnt on Java Island, while a default value of $75 \%$ was considered for other rice production centres in Indonesia.

These studies reveal that on a dry mass basis, rice straw contributes highest amount of residues open burnt with 19.3 million tonnes. This is closely followed by cassava residues with 18.5 million tonnes, then corn residues with 6.7 million tonnes and sugarcane with 0.4 million tonnes. In total, an annual amount of 44.9 million tonnes of crop residues were subjected to open burning. Streets et al. ${ }^{5}$ reported that in the year 2000 , with $17 \%$ of the crops subjected to open burning, an equivalent amount of $5.8 \mathrm{Tg}$ crop residues were eliminated by fire in Indonesia. Yevich and $\operatorname{Logan}^{31}$ reported that $73 \%$ of Indonesia's crop residues were open burned equating to $64.2 \mathrm{Tg}$. This large gap in the estimation of open burned crop residues is due to a number of factors like crops considered, residue-to-product ratio, and the fraction open burned. However, the latter appears to be the most important factor for estimating the amount of crops residues burned.

\section{Pollutant-specific emission factors of selected crops}

Emission factors specific to air pollutants and the corresponding types of crop residues subjected to open field burning are presented in Table 2. The emission factors are expressed in grams of released pollutant per kilogram of burned dry matter of crop residues. As mentioned before, the emission factors were obtained from literature review. For each crop, emission factors were selected that are country (Indonesia) or region (Asia) specific. When crop specific emission factors were not available, default values for crops in general were used ${ }^{32}$.

With regard to rice straw, emission factors for $\mathrm{CO}_{2}$, $\mathrm{CO}, \mathrm{CH}_{4}, \mathrm{NH}_{3}$ and $\mathrm{PM}_{2.5}$ were retrieved from Christian et $a l .{ }^{33}$ based on the rice straw open burning in Indonesia. For $\mathrm{NO}_{x}, \mathrm{SO}_{2}$ and non-methane volatile organic compounds (NMVOC), emission factors were sourced respectively from Kadam et al. ${ }^{34}$, Jenkins and Bhatnagar ${ }^{35}$ and the AP-42 database developed by the US Environmental Protection Agency ${ }^{36}$. Emission factors for $\mathrm{PM}_{10}$, elemental carbon (EC) and black carbon (BC) were sourced from Oanh et al. ${ }^{17}$ based on the rice straw open burning in Thailand.

With regard to corn, emission factors for $\mathrm{CO}_{2}, \mathrm{EC}$ and OC were collected from a study done in China by $\mathrm{Cao}$ et $a l .{ }^{37}$. Specific emission factors for $\mathrm{CO}, \mathrm{CH}_{4}, \mathrm{NO}_{x}, \mathrm{NH}_{3}$, NMVOC, $\mathrm{PM}_{10}$ and $\mathrm{PM}_{2.5}$ were retrieved from Dennis et $a l .{ }^{38}$ and for $\mathrm{SO}_{2}$, from Li et al. ${ }^{39}$.

In case of cassava, due to the scarcity of information on specific emission factors for this crop, default values were retrieved from different sources, like Zhang et al. ${ }^{40}$ for $\mathrm{CO}_{2}, \mathrm{CO}, \mathrm{CH}_{4}, \mathrm{NO}_{x}, \mathrm{SO}_{2}, \mathrm{NMVOC}$ and $\mathrm{PM}_{10}$, Andreae and Merlet ${ }^{32}$ for $\mathrm{N}_{2} \mathrm{O}$ and $\mathrm{NH}_{3}$ and Reddy and Venkataraman ${ }^{41}$ for $\mathrm{PM}_{2.5}$, EC and OC.

For sugarcane, specific emission factors for $\mathrm{CO}, \mathrm{CH}_{4}$, $\mathrm{NO}_{x}, \mathrm{NH}_{3}, \mathrm{NMVOC}, \mathrm{PM}_{10}$ and $\mathrm{PM}_{2.5}$ were sourced from 

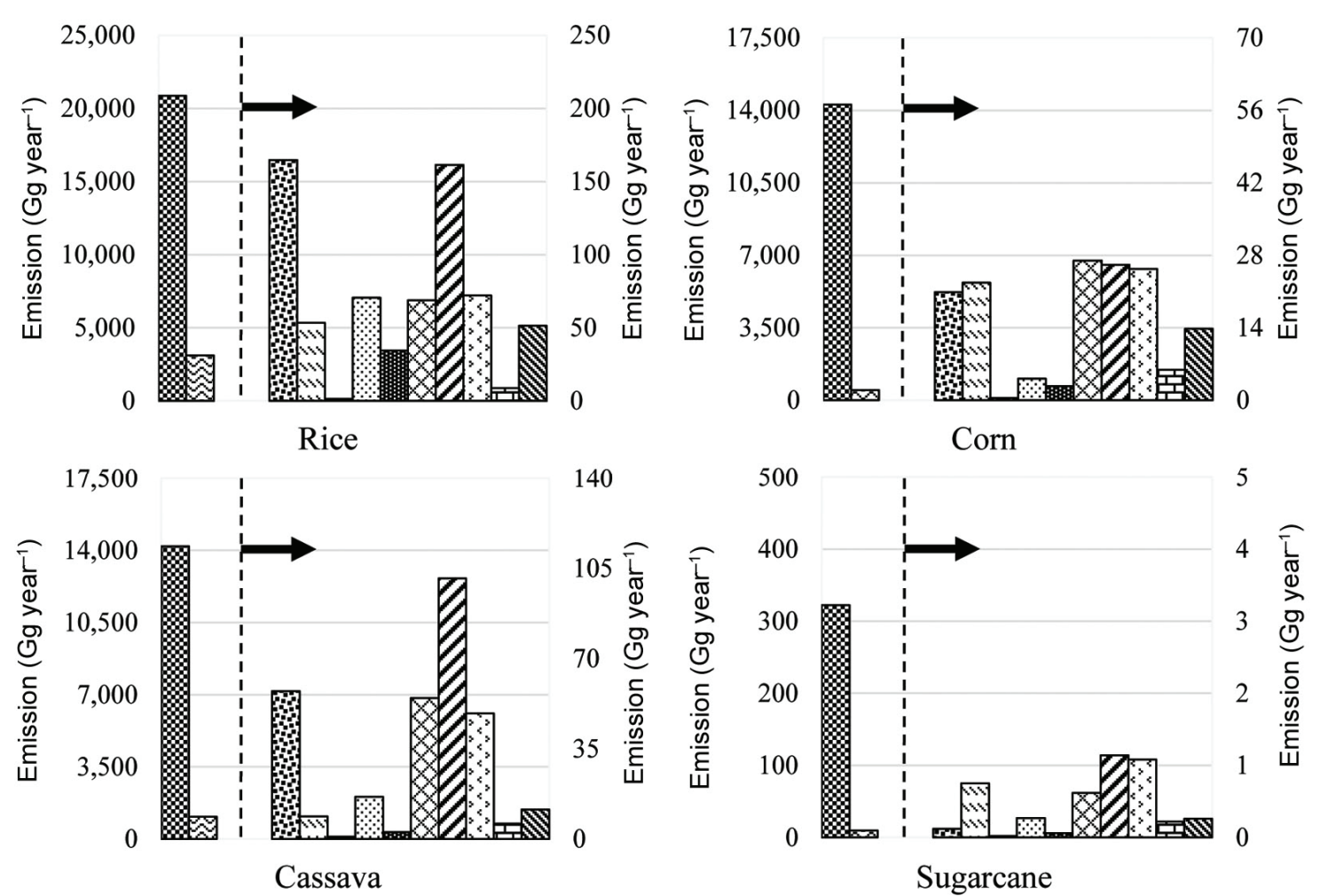

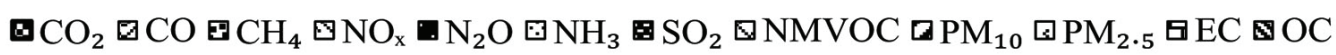

Figure 2. Annual emission of air pollutants from crop residues open burning in Indonesia.

Dennis et $a l^{38}$. Other emission factors were mainly retrieved from Zhang et al. ${ }^{40}$ and Penner et al. ${ }^{42}$.

\section{Emissions from crop residues open burning}

Figure 2 shows that the open burning of all the selected crop residues contributes largely towards $\mathrm{CO}_{2}$ emissions in the range of $85-96 \%$, followed by $\mathrm{CO}$ in the range of $3-13 \%$. The remaining fraction is contributed by the rest of the pollutants such as $\mathrm{CH}_{4}, \mathrm{NO}_{x}, \mathrm{~N}_{2} \mathrm{O}, \mathrm{NH}_{3}, \mathrm{SO}_{2}$, NMVOC, $\mathrm{PM}_{10}, \mathrm{PM}_{2.5}$, EC and organic carbon (OC). Depending on the crop, the contribution towards air pollutant emissions varies. Open burning of rice straw is observed to contribute the largest emission of all the pollutants as shown in Figure 2. After rice, cassava is the next crop to contribute most to the annual emissions of $\mathrm{CO}, \mathrm{CH}_{4}, \mathrm{~N}_{2} \mathrm{O}, \mathrm{NH}_{3}, \mathrm{SO}_{2}, \mathrm{NMVOC}, \mathrm{PM}_{10}, \mathrm{PM}_{2.5}$ and EC. Although sugarcane emissions appear to be the lowest and much less significant compared to rice, corn and cassava, it is the crop with the highest proportion of crop residues subjected to open burning (76\%). As the government of Indonesia is considering promoting biofuels such as ethanol for transport in the near future, an expansion of sugarcane plantations is expected to meet future policy targets. However, this might magnify emission of air pollutants if open burning practices are not controlled.
As mentioned earlier, Streets et al. ${ }^{5}$ had assessed emissions from biomass burning in Asia, including Indonesia. The studies included open burning of crop residues in general using default values from the literature. In particular, the proportion of crop residues subject to open burning was assumed to be $17 \%$ and default emission factors from Andreae and Merlet $^{32}$ were used. The results obtained for Indonesia are by using the default values from Streets et al. ${ }^{5}$ and the specific values identified in this study are compared for rice, corn, cassava and sugarcane (Figure 3). It is observed that the emissions are underestimated when default values from Streets et al. ${ }^{5}$ are used. This is particularly so for a number of climate pollutants. For instance, $\mathrm{CO}_{2}, \mathrm{~N}_{2} \mathrm{O}, \mathrm{NMVOC}, \mathrm{PM}_{2.5}$ and $\mathrm{EC}$ emissions estimated using country and crop specific values from this study are $60 \%$ higher than based on default values from Streets et al. ${ }^{5}$. In the same way, $\mathrm{CO}, \mathrm{CH}_{4}$, $\mathrm{NO}_{x}, \mathrm{NH}_{3}$ and $\mathrm{OC}$ emissions are about $30 \%$ higher while $\mathrm{PM}_{10}$ and $\mathrm{SO}_{2}$ are about $50 \%$ and $10 \%$ higher respectively. These findings indicate that the potential contribution of open burning of crop residues in Indonesia towards air pollution is underestimated. This also implies that the contribution of Indonesian open burning of crop residues to climate change is underestimated and the mitigation of such practices could lead to larger GHG emission reduction benefits than expected. 


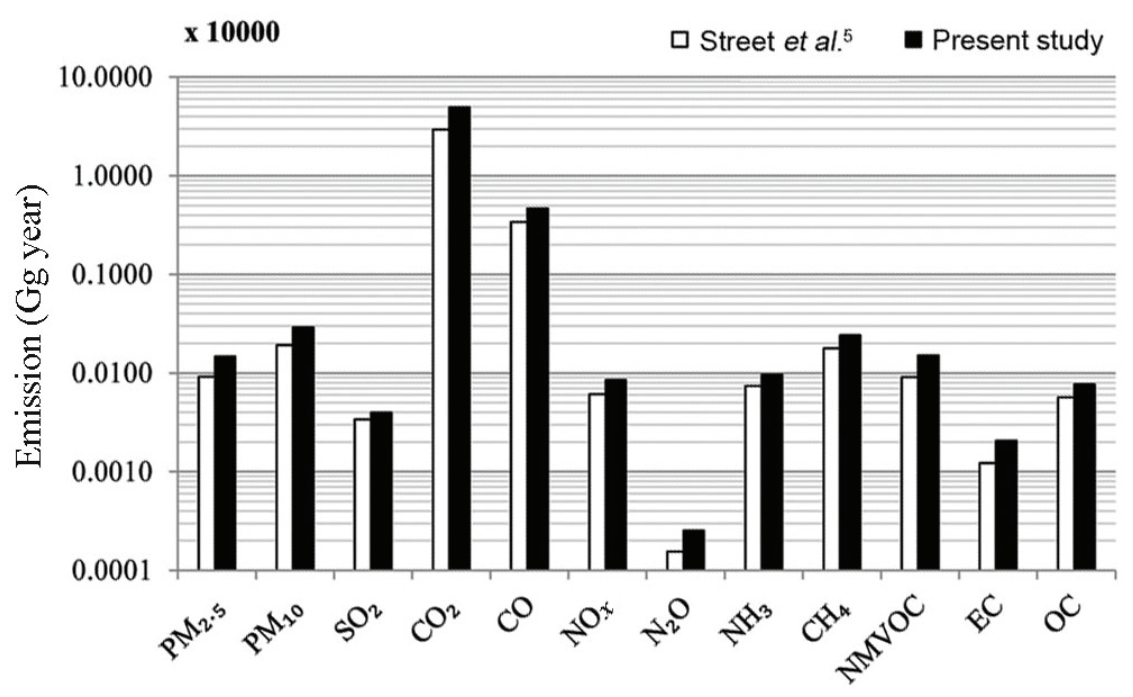

Figure 3. Comparative annual emissions of air pollutants from crop residues burning in Indonesia based on default factors from Streets et al. ${ }^{5}$ and specific factors as identified in this study.

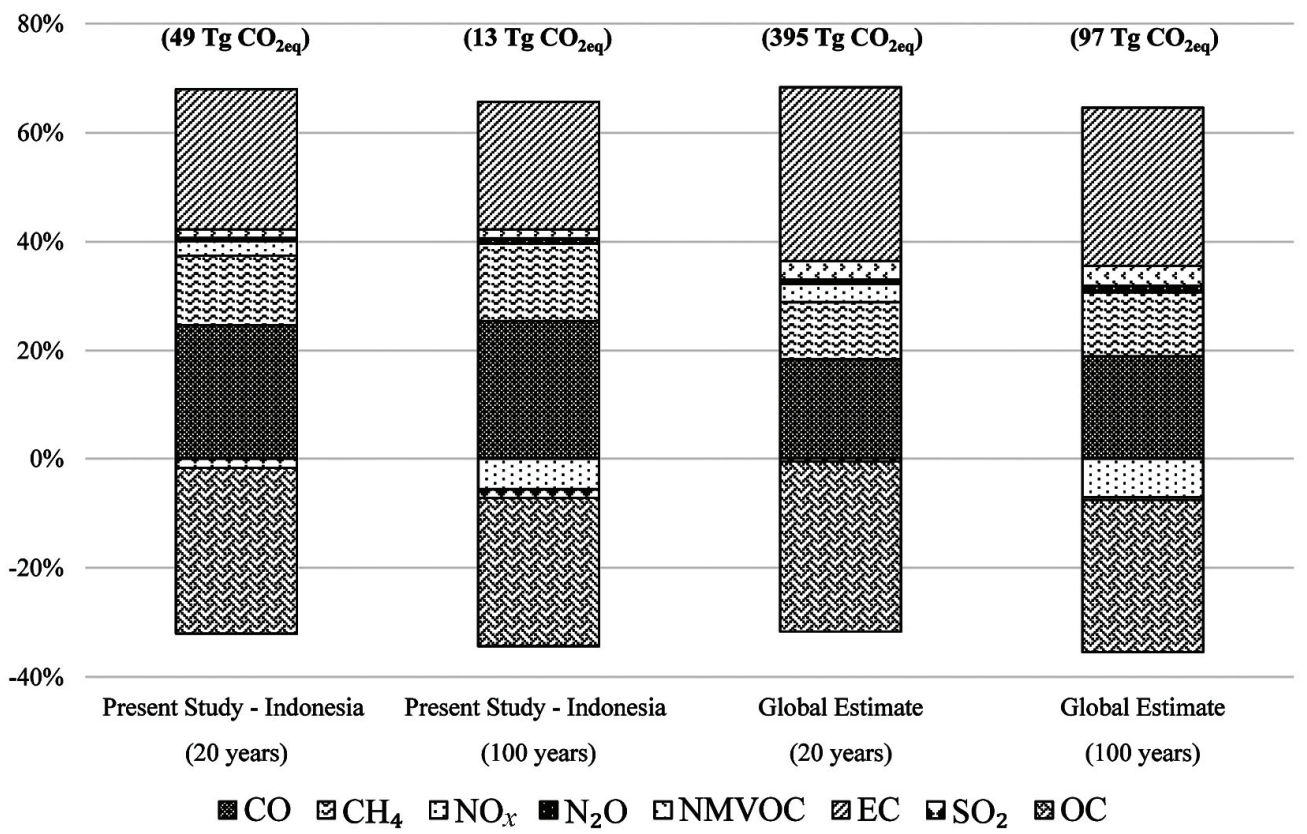

Figure 4. Contribution of Indonesia's crop residues open burning to the global agricultural open burning GWP. The values in parentheses correspond to the net GWP $\left(\mathrm{CO}_{2 \mathrm{eq}}\right)$.

\section{Contribution towards global open burning of crop residues $G W P$}

Figure 4 shows the percentage contribution of GHGs towards GWP and the short-lived climate changers emitted from open burning of crop residues in Indonesia in 2014. Figure 4 shows the percentage contribution to GWP of both warming $\left(\mathrm{CO}, \mathrm{CH}_{4}, \mathrm{NO}_{x}, \mathrm{~N}_{2} \mathrm{O}\right.$, NMVOC and $\mathrm{EC}$ with positive forcing) and cooling agents $\left(\mathrm{SO}_{2}\right.$ and $\mathrm{OC}$ with negative forcing). $\mathrm{CO}_{2}$ is not accounted for as it is considered as carbon neutral for annual crops as per the IPCC 2006 guidelines ${ }^{27}$. GWP is expressed in the form of $\mathrm{CO}_{2 \text { eq. }}$. The total GWP for 2014 is estimated at $93 \mathrm{Tg} \mathrm{CO}_{2 \text { eq }}$ (20 year horizon) and $25 \mathrm{Tg} \mathrm{CO}_{2 \mathrm{eq}}(100$ year horizon), while the net GWP is estimated at $49 \mathrm{Tg} \mathrm{CO} \mathrm{CO}_{2 \mathrm{eq}}$ and $13 \mathrm{Tg} \mathrm{CO}_{2 \mathrm{eq}}$ respectively. For both time horizons, in terms of positive forcing, the largest contributors to the total GWP are EC (38-39\%), $\mathrm{CO}(36-42 \%)$ and $\mathrm{CH}_{4}$ (19-24\%). These results highlight the importance of such pollutants to the GWP of crop residues subjected to open burning. The GWP of global crop residues subjected to open burning as estimated using data from Global Fire Emissions Database (GFED) 4 (ref. 43) for 2014 (Figure 4) amounts to about $395 \mathrm{Tg} \mathrm{CO}_{2 \mathrm{eq}}(20$ year) and $97 \mathrm{Tg}$ 
$\mathrm{CO}_{2 \mathrm{eq}}$ (100 year). Therefore, Indonesian open burning of crop residues contributes about $12-14 \%$ of the GWP of global crop residues open burning for both time horizons.

\section{Conclusion}

Major crops produced in Indonesia include rice, corn, cassava and sugarcane. It was found that about 45 million tonnes of these crop residues were open burned on an annual basis. This represents about $29 \%$ of the total amount of crop residues produced nationwide with rice contributing $43 \%$, cassava $41 \%$, corn $15 \%$ and sugarcane $1 \%$. In terms of emissions, it was found that they were dominated by $\mathrm{CO}_{2}(85-96 \%)$, followed by $\mathrm{CO}(3-13 \%)$. The remaining $1-3 \%$ of the emissions were found to be contributed by $\mathrm{CH}_{4}, \mathrm{NO}_{x}, \mathrm{~N}_{2} \mathrm{O}, \mathrm{NH}_{3}, \mathrm{SO}_{2}, \mathrm{NMVOC}$, $\mathrm{PM}_{10}, \mathrm{PM}_{2.5}$, EC and OC. However, among those pollutants, agents forcing positive climate change such as EC, $\mathrm{CO}$ and $\mathrm{CH}_{4}$ were identified to be the major contributors to the GWP of open burning of crop residues. Based on the country, crop and pollutant specific factors identified in this study, it was estimated that the Indonesian open burning of crop residues contributed a substantial 12$14 \%$ of the GWP of global crop residues open burning over a 20 year and 100 year horizon respectively. Such a contribution to climate change highlights the necessity of achieving the zeroburning policy that has been committed by Indonesia through the ASEAN agreement on transboundary haze pollution in 2014. Further studies are currently in progress to identify processes enabling to utilize those residues as energy feedstock for industrial applications.

1. Levine, J. S., Cofer, W. R., Cahoon, D. R. and Winstead, E. L., Biomass burning: a driver for global change. Environ. Sci. Technol., 1995, 29, 120A-125A

2. Yamasoe, M. A., Artaxo, P., Miguel, A. H. and Allen, A. G., Chemical composition of aerosol particles from direct emissions of vegetation fires in the Amazon Basin: water soluble species and trace elements. Atmos. Environ., 2000, 34, 1641-1653.

3. Crutzen, P. J. and Andreae, M. O., Biomass burning in the tropics: impacts on atmospheric chemistry and biogeochemical cycles. Science, 1990, 250, 1678-1679.

4. Levine, J. S., Global biomass burning: a case study of the gaseous and particulate emissions released to the atmosphere during the 1997 fires in Kalimantan and Sumatra, Indonesia. In Biomass Burning and its Inter-relationships with the Climate System (eds Innes, J. L., Beniston, M. and Verstraete, M. M.), Kluwer Academic Publishers, Netherlands, 2000, vol. 3, pp. 15-31.

5. Streets, D. G., Yarber, K. F., Woo, J. H. and Carmichael, G. R., Biomass burning in Asia: annual and seasonal estimates and atmospheric emissions. Global Biogeochem. Cy., 2003, 17(4), 1099.

6. Badarinath, K. V. S., Chand, T. R. K. and Prasad, V. K., Agriculture crop residue burning in the Indo-Gangetic Plains - a study using IRS-P6 AWiFS satellite data. Curr. Sci., 2006, 91(8), 10851089 .

7. Duan, F., Liu, X., Yu, T. and Cachier, H., Identification and estimate of biomass burning contribution to the urban aerosol organic carbon concentrations in Beijing. Atmos. Environ., 2004, 38, $1275-1282$.

8. Lenka, S., Lenka, N. K., Singh, R. C., Rao, A. S., Kundu, S., Raghuwansi, J. and Patidar, C. P., Greenhouse gas emission and soil properties as influenced by wheat biomass burning in vertisols of central India. Curr. Sci., 2014, 107(7), 1150-1154.

9. Gupta, P. K. et al., Residue burning in rice-wheat cropping system: causes and implications. Curr. Sci., 2004, 87(12), 17131717.

10. Oozeer, M. Y. et al., Numerical study of the transport and convective mechanisms of biomass burning haze in South-Southeast Asia. Aerosol. Air Qual. Res., 2016, 16, 2950-2963.

11. Pandey, K. and Sahu, L. K., Emissions of volatile organic compounds from biomass burning sources and their ozone formation potential over India. Curr. Sci., 2014, 106(9), 1270-1279.

12. Heil, A., Air pollution caused by large scale forest fires in Indonesia 1997. In Workshop on South-East Asian Land/Forest Fires: Science and Policy, Centre for Remote Imaging, Sensing and Processing, Singapore, 1998.

13. Rahman, S. A. et al., A long term study on characterization and source apportionment of particulate pollution in Klang Valley, Kuala Lumpur. Aerosol. Air Qual. Res., 2015, 15, 2291 2304.

14. Chan, F., Air pollution in Indonesia falls to its lowest levels; www.straitstimes.com/asia/se-asia/air-pollution-in-indonesia-fallsto-its-lowest-levels (accessed on 25 July 2017).

15. World Bank, Indonesia's fire and haze crisis; www.worldbank.org/en/news/feature/2015/12/01/indonesias-fire-and-haze-crisis (accessed on 25 September 2017).

16. FAO, Indonesia; www.fao.org/docrep/005/y4632e/y4632e01.htm (accessed on 10 September 2015).

17. Oanh, N. T. K., Bich, T. L., Tipayarom, D., Manadhar, B. R., Prapat, P. and Simpson, C. D., Characterization of particulate matter emission from open burning of rice straw. Atmos. Environ., 2011, 45(2), 493-502.

18. Gadde, B., Bonnet, S., Menke, C. and Garivait, S., Air pollutant emission from rice straw open field burning in India, Thailand and the Philippines. Environ. Pollut., 2009, 157, 1554-1558.

19. Mahmud, M., Assessment of atmospheric impacts of biomass open burning in Kalimantan, Borneo during 2004. Atmos. Environ., 2013, 78, 242-249.

20. Permadi, D. A. and Oanh, N. T. K., Assessment of biomass open burning emissions in Indonesia and potential climate forcing impact. Atmos. Environ., 2013, 78, 250-258.

21. Makarim, A. K. and Sumanto., S., Rice Straw: Management and Utilization, Research and Development Center of Agriculture, Ministry of Agriculture, Bogor, Indonesia, 2007.

22. Rumbayan, M., Biomass energy resources assessment in North Sulawesi. Biomass Energy Resour., 2004, 10(3), 223-226.

23. Sasongko, W. R., Wishnu, I. M. W. and Yohannes, G. B., Livestock farming system technology application for goat in a dry land village, Sambelia. Research and Development Center of Ministry of Agriculture, Bogor, Indonesia, 2004.

24. Ministry of Agriculture; www.pertanian.go.id/ap pages/mod/ datatp (accessed on 21 November 2015).

25. Yamane, T., Statistics. An Introductory Analysis, Harper and Row, New York, 2nd edn, 1967.

26. Andini, A., Rousset, P., Hasanudin, U. and Bonnet, S., Assessment of the proportion of crop residues subject to open burning available as energy feedstock in Indonesia. In Proceedings of the 6th International Conference on Sustainable Energy and Environment, Energy and Climate Change: Innovating for a Sustainable Future, Bangkok, Thailand, 2016.

27. Intergovernmental Panel on Climate Change, In 2006 IPCC guidelines for National Greenhouse Gas Inventories. Prepared by the National Greenhouse Gas Inventories Programme (eds Eggleston, H. S. et al.), IGES, Japan, 2006. 


\section{RESEARCH ARTICLES}

28. Turn, S. Q., Jenkins, B. M., Chow, J. C., Pritchett, L. C., Campbell, D., Cahill, T. and Whalen, S. A., Elemental characterization of particulate matter emitted from biomass burning: wind tunnel derived sources profile for herbaceous and wood fuel. J. Geophys. Res-Atmos., 1997, 102, 3683-3700.

29. Seiler, W. and Crutzen, P. J., Estimates of gross and net fluxes of carbon between the biosphere and atmosphere from biomass burning. Climatic Change, 1980, 2, 207-247.

30. Chang, C.-H., Liu, C.-C. and Tseng, P.-Y., Emissions inventory for rice straw open burning in Taiwan based on burned area classification and mapping using formosat-2 satellite imagery. Aerosol. Air Qual. Res., 2013, 13, 474-487.

31. Yevich, R. and Logan, J. A., An assessment of biofuel use and burning of agricultural waste in the developing world. Global Biogeochem. Cy., 2003, 17, 1095.

32. Andreae, M. O. and Merlet, P., Emissions of trace gases and aerosols from biomass burning. Global Biogeochem. Cy., 2001, 15, 955-966.

33. Christian, T. J. et al., Comprehensive laboratory measurements of biomass-burning emissions: Emissions from Indonesian, African, and other fuels. J. Geophys. Res., 2003, 108(D23), 4719-4732.

34. Kadam, K. L., Forrest, L. H. and Jacobson, W. A., Rice straw as a lignocellulosic resource: collection, processing, transportation, and environmental aspects. Biomass Bioenerg., 2000, 18, 369389.

35. Jenkins, B. M. and Bhatnagar, A. P., On the electric power potential from paddy straw in the Punjab and the optimal size of the power generation station. Bioresour. Technol., 1991, 37, 35-41.

36. US EPA, Emission Factor: Documentation for AP-42, Open Burning. Office of Air Quality Planning and Standards and Office of Air and Radiation, US Environmental Protection Agency, North Carolina, 1992, p. 34.

37. Cao, G., Zhang, X., Gong, S. and Zheng, F., Investigation on emission factors of particulate matter and gaseous pollutants from crop residue burning. Environm. Sci., 2008, 20(1), 50-55.

38. Dennis, A., Fraser, M., Anderson, S. and Allen, D., Air pollutant emissions associated with forest, grassland, and agricultural burning in Texas. Atmos. Environ., 2002, 36(23), 3779-3792.
39. Li, X., Wang, S., Duan, L., Hao, J., Li, C., Chen, Y. and Yang, L., Particulate and trace gas emissions from open burning of wheat straw and corn stover in China. Environ. Sci. Technol., 2007, 41(17), 6052-6058.

40. Zhang, J. et al., Greenhouse gases and other airborne pollutants from household stoves in China: a database for emission factors. Atmos. Environ., 2000, 34(26), 4537-4549.

41. Reddy, M. S. and Venkataraman, C., Inventory of aerosol and sulphur dioxide emissions from India. Part II-biomass combustion. Atmos. Environ., 2002, 36(4), 699-712.

42. Penner, J. E., Chuang, C. C. and Liousse, C., The contribution of carbonaceous aerosols to climate change. In Proceedings of the 14th International Conference on Nucleation and Atmospheric Aerosols, Helisinki, Finland, 1996.

43. GFED4, www.geo.vu.nl/ gwerf/GFED/GFED4/tables/ (accessed on 15 September 2017).

44. Koopman, A. and Koppejan, J., Agricultural and forest residue generation, utilization and availability. In Regional Consultation on Modern Application of Biomass Energy, FAO, Kuala Lumpur, Malaysia, 1997.

ACKNOWLEDGEMENTS. We thank the team from Research and Development Center for Tropical Biomass, Institute for Research and Community Services, University of Lampung, Indonesia for the support and guidance. We also thank the Joint Graduate School of Energy and Environment, Center of excellence for Energy Technology and Environment, King Mongkut's University of Technology Thonburi, Thailand and the French Agricultural Research and International Cooperation Organization (CIRAD), France, for providing the financial support.

Received 5 February 2018; revised accepted 17 July 2018

doi: $10.18520 / \mathrm{cs} / \mathrm{v} 115 / \mathrm{i} 12 / 2259-2266$ 